\title{
Is Tillage a Suitable Option for Weed Management in Conservation Agriculture?
}

\author{
Stéphane Cordeau * ${ }^{\mathbb{D}}$, Auxence Baudron and Guillaume Adeux \\ Agroécologie, AgroSup Dijon, INRAE, Univ. Bourgogne, Univ. Bourgogne Franche-Comté, \\ F-21000 Dijon, France; auxence.baudron@inrae.fr (A.B.); guillaume.adeux@inrae.fr (G.A.) \\ * Correspondence: stephane.cordeau@inrae.fr; Tel.: +33-380693267
}

Received: 1 October 2020; Accepted: 5 November 2020; Published: 10 November 2020

check for updates

\begin{abstract}
In Europe, conservation agriculture (CA) is currently challenged by higher weed pressure, potential glyphosate ban and reduced crop yield. Based on preliminary results and a critical analysis, we provide insights on how to assess the effect of introducing different levels of tillage intensity, after a long-term CA sequence, on weed communities and crop yield. The experiment compared three types of fallow management (ploughing (CT), reduced tillage (RT), no-till with glyphosate (NT)) on four fields after 17 years of no-plough, which ended with 7 years of $C A$. The introduction of tillage proved to be a major driver of weed communities before weeding (density, richness and composition) in winter wheat. Weed density and species richness before weeding was greatest in RT, intermediate in CT and lowest in NT. The number of grains per ear and crop yield increased with tillage intensity $(+11 \%$ for $\mathrm{RT},+31 \%$ for $\mathrm{CT})$. We provide avenues for future research through detailed methods and key references. Differences in winter wheat productivity were possibly related to enhanced soil structure and increased mineralisation of soil organic matter. Potential benefits of occasional ploughing will depend on the density and composition of the newly upwelled weed seedbank, which will need to be assessed before implementing tillage. From a multicriteria perspective, the long-term benefits associated with CA could largely exceed short-term yield increases associated with occasional tillage. Future studies will need to characterize the impact of occasional tillage operations on the long-term multiperformance of CA systems.
\end{abstract}

Keywords: weed diversity; weed composition; glyphosate; yield components; seedbank; no-till; occasional tillage; agroecology

\section{Introduction}

Weed management in Conservation Agriculture (CA) relies on three fundamental pillars: diversified crop rotation, permanent soil cover and absence of soil disturbance [1]. This systemic vision of CA, thereby differing from conservation tillage [2], considers these three pillars as the immutable foundation required to provide the ecosystem services associated with CA (e.g., increase in soil biological activity and soil aggregate stability). Potential glyphosate ban in Europe has raised concerns either from farmers or stakeholders as to how CA may break free from the use of this active compound, and few have been tackled by the scientific community to date [3]. A recent survey conducted by the ENDURE network (http://www.endure-network.eu/endure) in Europe [4] revealed occasional and recurrent uses of glyphosate, either in CA- or tillage-based systems. Such results encourage the investigation of alternative solutions along the substitution-to-redesign gradient [5]. The report also indicated that a diversity of non-chemical alternatives to glyphosate existed, but that their effectiveness, cost and adoption implications were highly variable and/or difficult to quantify [4].

Very few non-chemical alternatives to glyphosate, other than occasional tillage, are currently mature (i.e., efficient and available). As a consequence, the quest to fulfil the exact principles of CA 
mentioned above has hindered CA farmers in moving towards organic agriculture (i.e., CA ban the use of tillage) and organic farmers to move towards CA (i.e., organic agriculture ban the use of herbicide).

Rather than perpetuating the sterile debate between those considering CA through its means (i.e., the three pillars described above) and, therefore, banning the use of tillage, and those considering CA though its objectives (e.g., increasing soil heath), and therefore, willing to consider a wider set of weed management tools (including occasional and superficial tillage), we highlight that little is known on the influence of tillage in fields previously conducted under CA principles. Very few studies have tacked this issue [6,7], and information is particularly scarce in Europe, possibly due to the relatively recent introduction of CA [8]. Investigating the effect of different types of occasional tillage (timing, intensity, depth) and the underlying mechanisms should allow the more effective analysis of the benefits and drawbacks associated with potential alternatives to glyphosate.

\section{Is Tillage an Option in Conservation Agriculture and Why?}

No-till ensures that weed seeds remain on the soil surface, a condition deemed to be unfavourable to weed seed germination because of poor seed:soil contact [9] and increased weed seed mortality [10,11]. Moreover, the presence of a living mulch or crop residues on the soil surface can offset the environmental conditions required for weed seed germination and act as a mechanical barrier to weed establishment $[12,13]$. However, many studies have reported higher weed pressure under no-till than under ploughing $[14,15]$. Permanent no-till systems could provide a stable habitat for a new suite of adapted species, as observed for annual grasses, perennials and anemochorous/low seed mass species [16-18].

Occasional tillage could help to diversify selection pressures and cope with certain challenges encountered in no-till [6], such as the management of herbicide resistant-weeds [19] or other pests (e.g., slugs, voles) [20], soil compaction [21] or reduced crop productivity [21-24]. Extensive research has focused on how tillage intensity drives weed dynamics and/or crop yields, but few studies have investigated tillage effects in fields previously managed under CA principles for a long time. Different levels of tillage intensity could be considered, from superficial [25] to inversion tillage (i.e., rotational no-till) [26]. Farmers fear that occasional superficial tillage operations (e.g., stubble cultivation, rotary harrowing) will stimulate the superficial weed seedbank [27] and result in a massive flush of germinations $[28,29]$. Others advocate that ploughing with skim coulters after a no-till sequence will bury the superficial, enriched weed seedbank and upwell the deep, depleted weed seedbank [30-32]. Moreover, the introduction of occasional tillage has been shown to have variable effects on no-till crop productivity, ranging from a $10 \%$ yield increase at the rotation level [21] to a small (4.2\% in Díaz-Zorita et al. [23]) or no increase [6,7] in winter wheat (Triticum aestivum L.) yield.

In the following sections, we will (i) present preliminary results of a study investigating weed community (density, species richness, composition) and winter wheat (yield, yield components, grain quality) response to different levels of tillage intensity (no-till, superficial, ploughing) in fields previously managed under CA principles during 17 years (ten years of reduced tillage followed by seven years of strict no-till); and (ii) based on this experience, provide avenues for future research, detailed with methods and key references.

\section{Experimenting the Effect of Occasional Tillage in Conservation Agriculture}

\subsection{Material and Methods}

\subsubsection{Experimental Site and Set-Up}

The field experiment was conducted in 2017-2018 at the INRAE experimental farm in Bretenière, France ( $\left.47^{\circ} 14^{\prime} 11.2^{\prime \prime} \mathrm{N}, 5^{\circ} 05^{\prime} 56.1^{\prime \prime} \mathrm{E}\right)$, and set-up as a completely randomized block design. The four fields (i.e., statistical blocks) selected for the experiment were previously managed under CA principles (superficially tilled during the first 10 years, strict no-till during the last 7 years). The four fields were cropped according to a diversified 6-year crop sequence which included three winter crops 
(mainly oilseed rape, wheat and barley), one spring crop (barley) and one summer crop (sorghum or soybean). During the last 7 years of strict no-till, cover crops were sown during the summer fallow period. Over the last 17 years, weed control and cover crop termination was performed chemically, averaging 1.7 full dose herbicide applications per year ( $43 \%$ glyphosate, $24 \%$ anti-broad-leaved, $12 \%$ anti-grasses and $21 \%$ broad-spectrum). A detailed description of the practices implemented over the past 17 years can be found in Adeux et al. [14].

Within each 1.5 ha field, three $5 \mathrm{~m}$ wide strips (i.e., statistical unit, experimental plot) were defined after main crop harvest in 2017 (previous crop was winter wheat for two fields and oilseed rape (Brassica napus L. subsp. napus) for the other two). One strip was dedicated to conventional tillage (i.e., ploughing, CT), another to reduced tillage (i.e., superficial and non-inversion tillage, RT) and the last one was maintained under no-till (NT). Soil preparation prior to winter wheat sowing consisted of stubble cultivation in RT (8 cm deep, 10 October 2017), ploughing with skim coulters in CT ( $25 \mathrm{~cm}$ deep, 6 October 2017) and rotary harrowing in both RT and CT (8 cm deep, 13 October 2017). Glyphosate was applied at $1080 \mathrm{~g} / \mathrm{ha}$ during the fallow period (29 September 2017) in NT.

All field strips were then sown with winter wheat at 350 grains $/ \mathrm{m}^{2}$ (variety Nemo, $3 \mathrm{~cm}$ sowing depth, 15 October 2017). Sowing was performed with a mechanical seed drill (Amazone D9, $13.8 \mathrm{~cm}$ row spacing) in RT and CT and with a direct driller (JD 750A, $16.7 \mathrm{~cm}$ row spacing) in NT. After sowing, all management practices were replicated identically across tillage treatments so as to assess the unique effect of tillage intensity. Nitrogen fertilisation was split into 2 applications-i.e., $50 \mathrm{~kg} \mathrm{~N} / \mathrm{ha}$ on the 22 February 2018 and $116 \mathrm{~kg} \mathrm{~N} / \mathrm{ha}(+33 \mathrm{~kg} \mathrm{~S} / \mathrm{ha}$ ) on the 10 April 2018. Septoria leaf spot was controlled on the 7 May 2018 with $50 \mathrm{~g} /$ ha of benzovindiflupyr, $40 \mathrm{~g} / \mathrm{ha}$ of cyproconazole and $375 \mathrm{~g} / \mathrm{ha}$ of chlorothalonil. Wheat yellow rust was controlled on the 16 May 2018 with $50 \mathrm{~g} / \mathrm{ha}$ of benzovindiflupyr. Weed control in winter wheat was performed late (solely on the 22 March 2018) so as to allow a full expression of the autumn- and spring-emerging weed flora and consisted of a tank mixture of $9 \mathrm{~g} / \mathrm{ha}$ of mesosulfuron, $60 \mathrm{~g} / \mathrm{ha}$ of diflufenican, $3 \mathrm{~g} / \mathrm{ha}$ of iodosulfuron and $25 \mathrm{~g} / \mathrm{ha}$ of amidosulfuron.

\subsubsection{Measures}

The soil seedbank was assessed in 2010 (i.e., prior to the strict no-till phase) by collecting 10 soil samplings (each being a composite of 10 soil cores) from a $100 \mathrm{~m}^{2}$ zone in each field. Each core was split into superficial (0-10 cm depth) and deep horizon (10-30 cm). Weed seeds were extracted from the soil using the sieving method and submitted to a greenhouse germination bioassay [33]. Emerged seedings were identified at the species level and counted. After one year of succeeding cohorts, the residual seeds were identified and counted under a binocular magnifier. According to the diameter of the soil probe, the seed bank was then expressed as seed $\mathrm{m}^{-2}$, both in the superficial and deep soil horizons.

In 2017-2018, four $0.36 \mathrm{~m}^{2}$ quadrats were randomly positioned within each strip and maintained fixed during the growing season. Therefore, wheat density, weed biomass, wheat yield and yield components were characterized in the same quadrats. Quadrat dimensions (length and width) were adapted to row spacing in order to avoid overrepresentation of the row or inter-row. Wheat density was assessed on the 8 February 2018 by counting the number of wheat seedlings. Aboveground weed biomass was sampled at crop maturity (11 July 2018), dried for $48 \mathrm{~h}$ at $80^{\circ} \mathrm{C}$ and weighed. Concurrently, wheat ears were counted, harvested, submitted to a fixed station threshing machine, and wheat grains were dried for $48 \mathrm{~h}$ at $80^{\circ} \mathrm{C}$ in order to assess winter wheat yield and thousand kernel weight (average of four random and independent samples drawn from each quadrat). For each quadrat, a random 100 $\mathrm{g}$ sample of fresh grain was preserved in order to assess specific weight and protein content (humidity was also assessed in order to compute total quadrat yield at $0 \%$ moisture content). The number of ears per plant was obtained by dividing the number of ears per quadrat by wheat density per quadrat. The number of grains per ear was obtained by dividing winter wheat yield by kernel weight and the number of ears per quadrat.

Weed community composition was assessed before (8 February 2018) and after (22 May 2018) weeding in $16 \mathrm{~m}^{2}$ zones around each quadrat (i.e., 4 zones per strip). Following the methodology of 
Yvoz et al. [34], each weed species present in the zone was identified and assigned a class of abundance (precisely counted when the density $<9$ individuals $/ 16 \mathrm{~m}^{2}$; from 9 to 15 individual $/ 16 \mathrm{~m}^{2}$ : class 1 ; from 1 to 2 individuals $/ \mathrm{m}^{2}$ : class 2; from 3 to 19 individuals $/ \mathrm{m}^{2}$ : class 3 ; from 20 to 49 individuals $/ \mathrm{m}^{2}$ : class 4; from 50 to 500 individuals $/ \mathrm{m}^{2}$ : class 5). Total weed density (i.e., sum of each species' centre of class) and species richness (i.e., the number of weed species) was computed based on the measures made in these $16 \mathrm{~m}^{2}$ zones.

\subsubsection{Economic Evaluation}

Farming practices implemented in the three tillage treatments only varied during the summer fallow period (i.e., glyphosate application in NT vs. different types of tillage operations in CT and RT) and at sowing (i.e., using a direct-seeding driller for NT and a conventional driller for CT and RT). Following the methodology and reference prices of Lechenet et al. [35,36], production costs included mechanisation costs (sprayer for herbicide and fungicide applications (6.41 EUR/ha), ploughing (34.70 EUR/ha), superficial tillage (7.25 EUR/ha with a cultivator and $34.28 \mathrm{EUR} / \mathrm{ha}$ with a power harrow), sowing (25.26 EUR/ha with a conventional driller and $29.98 \mathrm{EUR} / \mathrm{ha}$ with a direct-driller), fertiliser spreader (19.89 EUR/ha), harvest combine (94.14 EUR/ha)), input costs at the applied dose (treated wheat seeds (103.74 EUR/ha), glyphosate (9.89 EUR/ha), in-crop herbicides (68.69 EUR/ha), fungicides (56.33 EUR/ha)) and fuel costs (ploughing (17 L/ha), superficial tillage (10 L/ha with a cultivator and $15 \mathrm{~L} /$ ha with a power harrow), sowing $(10 \mathrm{~L} /$ ha for a conventional driller and $13 \mathrm{~L} /$ ha for a direct-driller), sprayer ( $2 \mathrm{~L} / \mathrm{ha})$, fertiliser spreader $(2 \mathrm{~L} / \mathrm{ha})$, harvest combine $(23 \mathrm{~L} / \mathrm{ha})$ ). Gross products were computed as the mathematical product between observed mean yield in each treatment and the sell price of winter wheat. Due to the variability of fuel, nitrogen and wheat sell prices, the economic evaluation was performed over 12 different price scenarios (reference prices from 2005 to 2017 in France). Fuel prices ranged from 0.47 to 0.76 EUR/L, nitrogen from 0.66 to 1.09 EUR/kg $\mathrm{N}$ and wheat sell prices ranged from 109.11 to $251.34 \mathrm{EUR} / \mathrm{t}$. The gross margin was computed as the difference between the gross product and the sum of the production costs (mechanisation, fuel, inputs). Finally, the mean, standard deviation (SD) and coefficient of variation (CV, as the standard deviation divided by the mean, indicator of robustness) were computed over the different references of the 2005-2017 period. The means of CT and RT treatments were also expressed as a ratio of the NT treatment, which is considered here as the reference.

\subsubsection{Statistical Analysis}

All regression analyses were performed with the lme4 package of the R software version 3.3.2 so as to account for non-independence of data points. Regression analysis were either performed at the quadrat (yield, yield component, weed biomass), zone level (weed density and richness) or average plot value level (gross margin). Linear mixed-effects models were used to analyse continuous response variables (ln transformed weed density, weed biomass, 1000-kernel weight, yield, specific weight, protein content, gross margin). Mixed Poisson regression was used to analyse whole, non-negative response variables (species richness, crop density, number of ears per plant, number of grains per ear). Overdispersion in Poisson regression was accounted for by the addition of an observation-level random effect. All response variables (except gross margin) were regressed against field (i.e., blocks, thereby accounting for the different combinations of soil type and preceding crops) and tillage treatment. Tillage strip was considered as a random effect in all models (except gross margin) so as to account for pseudoreplication. Gross margin was simply regressed against tillage treatment and the twelve annual scenarios were considered as random effects. Significance of tillage effects was assessed through type III Wald Chi-squared tests using the Anova function of the car R package. Contrasts between tillage treatments were adjusted using the emmeans R package. Partial Canonical Correspondence Analysis (pCCA) was performed to visualize and assess tillage effects on weed community composition. Field effects were partialled out to highlight tillage effects. Species were described by their ln-transformed centre of class of abundance. Significance of tillage effects was assessed using permutation tests 
( $n=1296$-i.e., complete enumeration). Tillage strip pseudoreplicates were always permuted together within a field.

\subsection{Results and Discussion}

Tillage treatments significantly affected weed communities before weeding in 2017 (Table 1). Total weed density and species richness before weeding was greatest in RT, intermediate in CT and lowest in NT (Table 1). In 2010, prior to the strict no-till phase, the weed seedbank assessment revealed that the superficial horizon was slightly more species rich $(0-10 \mathrm{~cm}: 12 \pm 2.7$ species; $10-30 \mathrm{~cm}$ : $9.2 \pm 3.1$ species; paired $t$-test $p$-value $<0.01)$ and roughly four times more abundant $(0-10 \mathrm{~cm}$ : $40,099 \pm 17,043$ seeds $/ \mathrm{m}^{2} ; 10-30 \mathrm{~cm}: 11,069 \pm 4956$ seeds $/ \mathrm{m}^{2}$; paired $t$-test $p$-value $\left.<0.0001\right)$. Indeed, $77.1 \%$ of weed seeds were concentrated in the $0-10$ horizon, the only horizon stimulated by stubble cultivation and rotary harrowing in RT seven years later. Such distribution of weed seeds throughout the soil profile is congruent with previous studies [10,37] and thus, greater weed emergence before weeding in RT than NT was expected. Weed seeds which were initially concentrated on the soil surface and in the superficial soil horizon (because of the previous 17 years of no-plough and the last 7 years of strict no-till) were then incorporated in the top soil-i.e., placed in more favourable conditions to germinate [9]. Higher weed emergence in CT than NT was, however, unexpected. Reasons which could explain this phenomena include the upwelling of persistent weed seeds (e.g., Fumaria officinalis or Sinapis spp.) [38-41] and/or the incomplete burial of weed seeds initially present in the top horizon (e.g., Alopecurus myosuroides) [31].

The estimated mean density of $A$. myosuroides, the most problematic weed of the experiment, was higher in RT than in CT or NT but could not be separated between CT and NT (Table 1). Nevertheless, observed density of $A$. myosuroides never exceeded 11.5 plants $/ \mathrm{m}^{2}$ in CT whereas it reached 35 and 275 plants $/ \mathrm{m}^{2}$ once in both RT and NT. Total weed density before weeding was also more variable in RT (2 to 319 plants $/ \mathrm{m}^{2}$ ) and NT (3 to 275 plants $/ \mathrm{m}^{2}$ ) than in CT (1 to 94 plants $/ \mathrm{m}^{2}$ ). A. myosuroides was only present at high densities in one out of four fields, where the greater performance of ploughing could not be highlighted due to low statistical power and high variability (due to the patchy distribution of the species). The discrepancy between our results and previous studies (i.e., occasional tillage reduces weed density [6,7]) may arise from (i) careful monitoring and management of problematic species over the past years [14] or (ii) the presence of persistent weed seeds in deeper soil horizons.

Differences in species richness and abundance transcribed into a significant tillage effect on weed community composition before weeding (Figure 1, 12.17\% of partial variation explained, $\mathrm{F}=2.91$, $\operatorname{Pr}(>\mathrm{F})=0.009)$. Of the 10 most abundant species observed before weeding $(99 \%$ of total abundance before weeding), two were associated with CT (F. officinalis and Myosotis arvensis), four to RT (Sinapis spp., Sonchus asper, Veronica hederifolia and Viola arvensis), two with both NT and RT (A. myosuroides and Lapsana communis), and one with both CT and RT (Lysimachia arvensis).

Weed density (4 to 13 plants $/ \mathrm{m}^{2}$ ), weed biomass ( 1 to $15 \mathrm{~g}$ of dry matter $/ \mathrm{m}^{2}$ ) and species richness after weeding were similar across tillage treatments (Table 1). Similarly, tillage treatments had no effect on weed community composition after weeding (data not shown, $9.29 \%$ of partial variation explained, $\mathrm{F}=2.15, \operatorname{Pr}(>\mathrm{F})=0.07)$. These results highlight the tremendous potential of herbicides to homogenize initially contrasted weed flora and the difficulty to link agronomic practices and weed observations, when the latter is made after weeding [16]. Out of the four yield components assessed, only the number of grains per ear was significantly affected by tillage treatments (Table 1). CT and RT produced 31 and $11 \%$ more grains per ear than NT, respectively, resulting in similar increases in grain yield. Specific weight and protein content were not affected by tillage treatments (Table 1). Higher crop yields under CT probably resulted from increased mineralisation of soil organic matter [42] or enhanced soil structure [21], rather than lower weed:crop competition, as reflected by an overall low weed biomass after weeding, across all tillage treatments. 
Table 1. Effect of tillage treatments (CT: conventional tillage, RT: reduced tillage, NT: no-till) implemented prior to winter wheat sowing in fields conducted under CA principles during 17 years, on weeds (density, richness, biomass), winter wheat yield and grain quality (least square mean \pm standard error). Tillage systems sharing identical letters are not significantly different at $p<0.05$ (bold). DM: dry matter.

\begin{tabular}{|c|c|c|c|c|c|}
\hline \multirow[b]{2}{*}{ Response Variable } & \multicolumn{5}{|c|}{ Tillage System } \\
\hline & $x^{2}$ & $\operatorname{Pr}\left(>x^{2}\right)$ & $\mathrm{CT}$ & RT & NT \\
\hline $\begin{array}{l}\text { Weed density before weeding } \\
\qquad\left(\text { plants } / \mathrm{m}^{2}\right)\end{array}$ & 31.03 & $<0.0001$ & $12 \pm 4 b$ & $33 \pm 10 c$ & $5 \pm 2 \mathrm{a}$ \\
\hline $\begin{array}{c}\text { Alopecurus myosuroides density before } \\
\text { weeding (plants } / \mathrm{m}^{2} \text { ) }\end{array}$ & 9.14 & 0.01 & $2 \pm 1 \mathrm{a}$ & $6 \pm 2 b$ & $2 \pm 1 \mathrm{a}$ \\
\hline $\begin{array}{l}\text { Weed density after weeding } \\
\left(\text { plants } / \mathrm{m}^{2}\right)\end{array}$ & 18.49 & $<0.0001$ & $4 \pm 1 \mathrm{a}$ & $13 \pm 2 b$ & $8 \pm 2 b$ \\
\hline $\begin{array}{l}\text { Species richness before weeding } \\
\left(\mathrm{nb} . \text { species } / 16 \mathrm{~m}^{2}\right)\end{array}$ & 27.51 & $<0.0001$ & $7.4 \pm 0.7 \mathrm{~b}$ & $9.9 \pm 0.8 c$ & $4.9 \pm 0.5 \mathrm{a}$ \\
\hline $\begin{array}{l}\text { Species richness after weeding } \\
\left(\mathrm{nb} . \text { species } / 16 \mathrm{~m}^{2}\right)\end{array}$ & 5.47 & 0.06 & $6.6 \pm 0.6 \mathrm{a}$ & $6.6 \pm 0.6 \mathrm{a}$ & $8.5 \pm 0.7 \mathrm{a}$ \\
\hline $\begin{array}{l}\text { Weed biomass at crop maturity } \\
\qquad\left(\mathrm{g} \mathrm{DM} / \mathrm{m}^{2}\right)\end{array}$ & 18.49 & $<0.0001$ & $1 \pm 0$ a & $15 \pm 10 b$ & $3 \pm 2 a b$ \\
\hline Crop density (nb. plants $/ \mathrm{m}^{2}$ ) & 5.66 & 0.06 & $190 \pm 6 a$ & $206 \pm 6 a$ & $209 \pm 6 a$ \\
\hline Number of ears per plant & 0.10 & 0.95 & $2.5 \pm 0.1 \mathrm{a}$ & $2.5 \pm 0.1 \mathrm{a}$ & $2.5 \pm 0.1 \mathrm{a}$ \\
\hline Number of grains per ear & 51.73 & $<0.0001$ & $40.1 \pm 1.1 \mathrm{c}$ & $34.1 \pm 0.9 b$ & $30.7 \pm 0.8 \mathrm{a}$ \\
\hline 1000 kernel weight (g DM) & 7.71 & 0.02 & $37.5 \pm 0.9 \mathrm{a}$ & $35.6 \pm 0.9 \mathrm{a}$ & $35.2 \pm 0.9 \mathrm{a}$ \\
\hline Yield (t DM/ha) & 16.87 & 0.0002 & $7.1 \pm 0.4 \mathrm{~b}$ & $6.1 \pm 0.3 \mathrm{a}$ & $5.5 \pm 0.3 \mathrm{a}$ \\
\hline Specific weight (g/L) & 4.99 & 0.08 & $756 \pm 5 a$ & $751 \pm 5 \mathrm{a}$ & $744 \pm 5 a$ \\
\hline Protein content (\%) & 0.14 & 0.93 & $12.5 \pm 0.2 \mathrm{a}$ & $12.6 \pm 0.2 \mathrm{a}$ & $12.6 \pm 0.2 \mathrm{a}$ \\
\hline
\end{tabular}

Gross products were on average 7 and $9 \%$ greater in CT $(1291 \pm 294 \mathrm{EUR} / \mathrm{ha}, \mathrm{CV}=0.23)$ and RT $(1311 \pm 299 \mathrm{EUR} / \mathrm{ha}, \mathrm{CV}=0.23)$ than in NT $(1208 \pm 275 \mathrm{EUR} / \mathrm{ha}, \mathrm{CV}=0.23)$, respectively. The mechanisation costs were $26 \%$ (267 EUR/ha) and 13\% (240 EUR/ha) greater in CT and RT than in NT (213 EUR/ha), respectively. The fuel costs were on average 54 and $40 \%$ greater in CT ( $47 \pm 8 \mathrm{EUR} / \mathrm{ha}$, $\mathrm{CV}=0.18)$ and RT $(42 \pm 7 \mathrm{EUR} / \mathrm{ha}, \mathrm{CV}=0.18)$ than in NT (30 $\pm 5 \mathrm{EUR} / \mathrm{ha}, \mathrm{CV}=0.18)$, respectively. The total production costs were on average 11 and $6 \%$ greater in CT $(697 \pm 28 \mathrm{EUR} / \mathrm{ha}, \mathrm{CV}=0.04)$ and RT $(665 \pm 28 \mathrm{EUR} / \mathrm{ha}, \mathrm{CV}=0.04)$ than in NT $(626 \pm 27 \mathrm{EUR} / \mathrm{ha}, \mathrm{CV}=0.04)$, respectively. The gross margins were on average 2 and $11 \%$ greater in CT (594 $\pm 278 \mathrm{EUR} / \mathrm{ha}, \mathrm{CV}=0.47)$ and RT (646 $\pm 283 \mathrm{EUR} / \mathrm{ha}$, $\mathrm{CV}=0.44)$ than in NT $(581 \pm 262 \mathrm{EUR} / \mathrm{ha}, \mathrm{CV}=0.45)$, respectively. Computed with references prices from the 2005-2017 period, gross margin was significantly greater in RT than in CT and NT $(p<0.001)$. Thus, higher winter wheat productivity in RT than in NT overcompensated for greater production costs in RT (particularly mechanisation and fuel costs), whereas it was not the case for CT. Nevertheless, such tillage operations could affect long-term profitability as Diaz-Zorita et al. [23] reported lower subsequent summer crop yield after reintroducing tillage. 


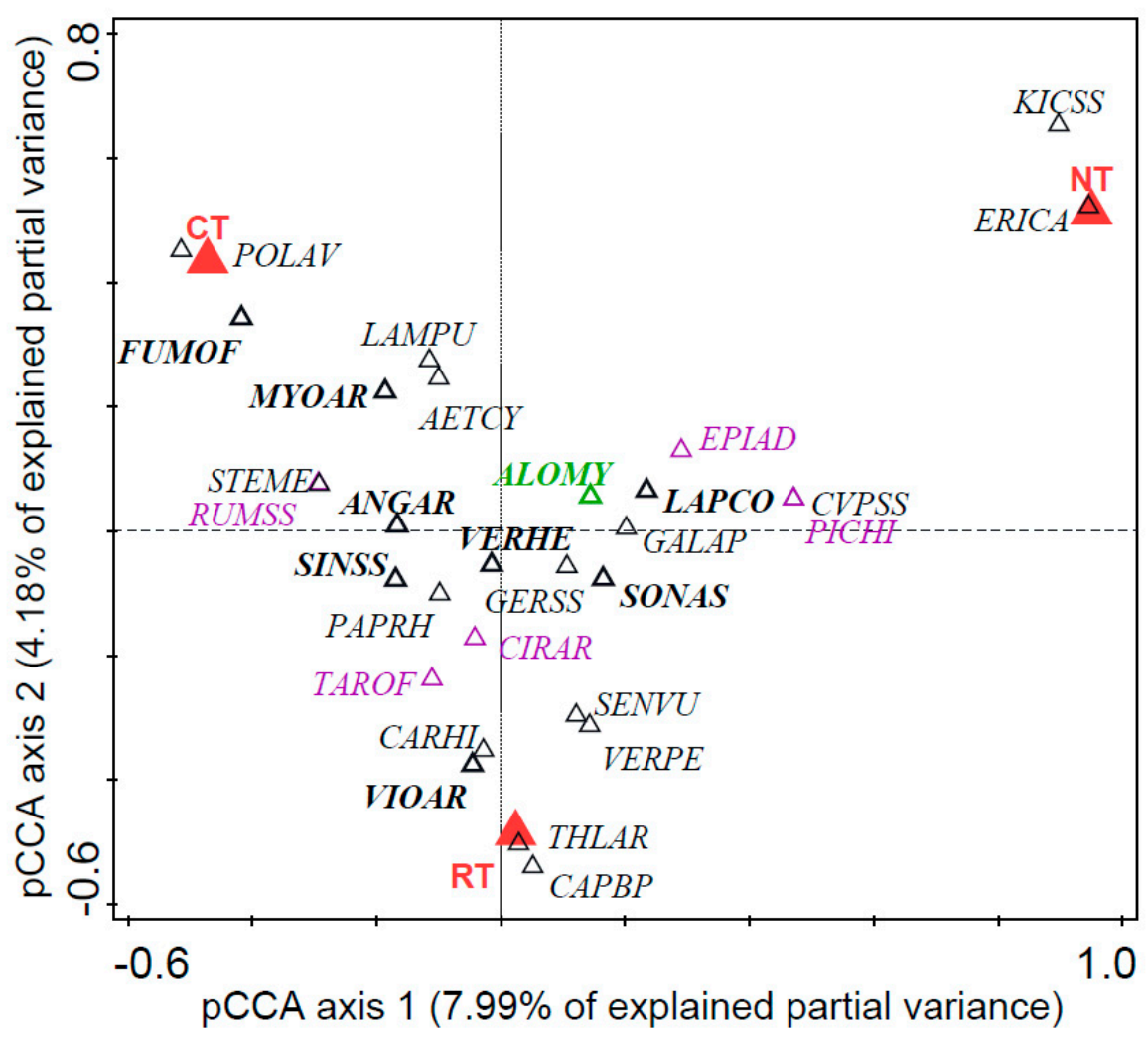

Figure 1. Partial Canonical Correspondence Analysis (pCCA) highlighting the effect of tillage treatments (CT: conventional tillage, RT: reduced tillage, NT: no-till) on weed community composition before weeding, after partialling out field effects. Species are named according to EPPO codes (https://gd.eppo.int/). The 10 most abundant species are highlighted in bold. Species names written in green and purple refer to grasses and pluri-annual species, respectively.

\section{Avenues for Future Research}

These preliminary results shed light on the short-term effect of different types of tillage on weed communities, weed:crop interference and crop performance in fields previously conducted under CA principles. However, methods could be adapted to investigate a hypothesis concerning the underlying mechanisms. Hence, we provide insights for future research, detailing hypotheses, methods and key references for the implementation of such studies (Table 2).

Occasional superficial tillage appeared as the worst option, at least when implemented shortly before sowing. However, results suggest that ploughing could be a viable weed management option in the case of a depleted deep weed seedbank. We argue that seedbank and seed distribution through the soil profile should be assessed before implementing a tillage experiment (Figure 2). Mahe et al. [33] provide a critical review to guide the selection of methods for seedbank assessment (Table 2). In the experiment, higher weed emergence in CT than NT was unexpected and could be explained by the incomplete burial of weed seeds initially present in the top horizon. Thus, weed seeds mimics (e.g., coloured plastic beads of different shapes and sizes) could be placed on the soil surface prior to tillage (Figure 2) and their vertical distribution could be assessed with soil probes after tillage [31]. A functional analysis of the deep weed seedbank could allow to investigate whether or not weed communities in CT were mainly represented by newly upwelled weed species with persistent seedbanks [38]. Similarly, a functional analysis of the emerged communities over the past years [43] could help to forecast the efficacy of occasional ploughing (e.g., seed mass will determine its ability to germinate in deeper horizons, thickness of seed coating will determine seed longevity and hence, the frequency at which ploughing can be implemented to remain a useful tool). 
Phenomenological experiments (i.e., we did this, we saw that) do not allow to identify the processes underlying the effects of tillage-i.e., whether changes in weed density and aboveground community composition were due to changes in vertical distributions of seeds in the soil profile, and/or changes in microsite conditions affecting germination (i.e., regeneration niches [44]). We thus argue that environmental conditions (e.g., soil $\mathrm{N}$ content and mineralization, soil temperature and moisture) before and after tillage, and particularly during the early stage of crop growth, should be described (Table 2). Indeed, previous studies have shown that weed seed germination was favoured by light exposure and open air seed imbibition prior to weed seed burial [45]. Tillage can also generate physical and chemical reactions which favour the germination of initially buried weed seeds, such as increased soil temperature, light penetration and resource availability [27]. Changes in soil moisture and temperature could also have affected crop and weed growth, and hence weed:crop interference (Table 2).
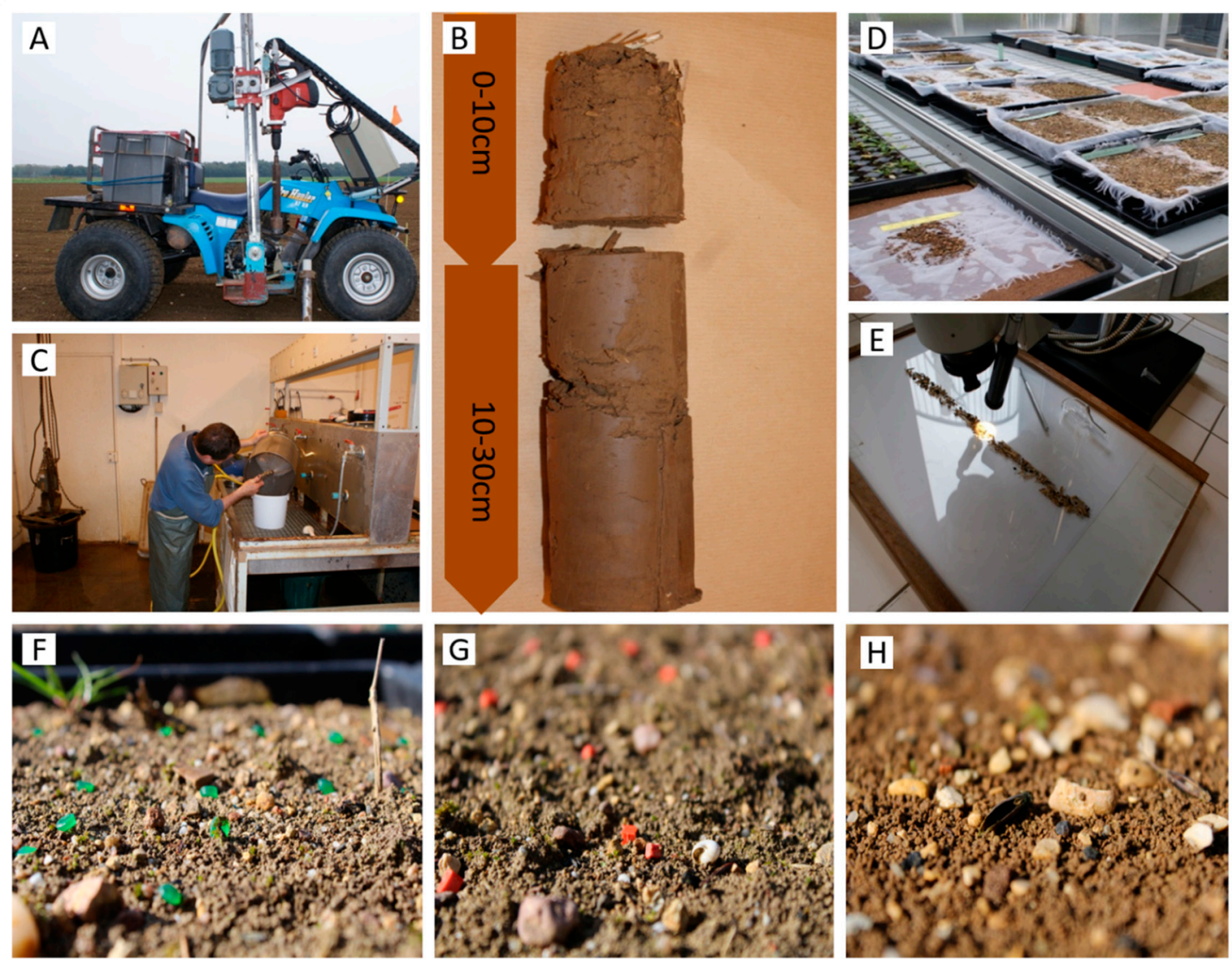

Figure 2. Seedbank assessment before and after tillage operations. (A) Soil sampling with an auger. (B) Separation of the superficial and deep horizons. (C) Extraction of weed seeds using the sieving method. (D) Greenhouse germination bioassay of the previously extracted seeds. (E) Identification and counting of non-germinated seeds under a binocular magnifier. Coloured plastic beads of different sizes, weights, and densities could be placed on the soil surface prior to tillage (F,G) so as to mimic weed seeds $(\mathbf{H})$, and allow the assessment of their vertical distribution after tillage, potentially highlighting incomplete burial. Copyright (C) INRAE.

The comparison of different tillage types through a factorial approach partially inhibited the assessment of other agronomically coherent strategies. Superficial tillage operations close to crop sowing did not appear sustainable because in-crop weed seed germination was stimulated. We argue that experiments could test different management tactics during the fallow period, designed with a systemic and integrated weed management approach (Table 2). For example, the repetition of 
superficial tillage operations (as in false seed bed tactics), combined with delayed sowing, could be a more viable solution to deplete the weed seedbank during the fallow period [46].

In addition, repeated tillage operations might override other benefits associated with CA, such as limited soil erosion, increased soil water retention [47] or long-term weed management. Considering tillage prior to sowing will only provide partial weed control, a more profound redesign of the cropping system might appear as a more promising solution, even if it is definitively more complex. Longer studies are needed to characterize potential trade-offs between short-term winter wheat yield increase and long-term agronomic performance (Table 2). For example, Diaz-Zorita et al. [23] reported a slight increase in winter wheat yield after tillage which was largely compensated by lower subsequent summer crop yield, phenomena unobserved by Crawford et al. [6]. Moreover, a short term increase in winter wheat yield does not necessarily compensate for higher mechanisation costs related to tillage operations [23]. From a societal multicriteria perspective, the long-term benefits associated with CA—e.g., climate mitigation, erosion control, water conservation [47]—could largely exceed short-term yield increases associated with occasional tillage [48]. Future studies will need to characterize the impact of occasional tillage operations on the long-term multiperformance of CA systems [3]. For example, such studies could allow to highlight, through a multicriteria assessment [3,7,22,49-53], the benefits and drawbacks associated with either maintaining strict CA (including the use of glyphosate) or introducing occasional tillage.

\section{Conclusions}

Conservation agriculture (CA) is recognized for its multiple ecosystem services but is currently challenged by higher weed pressure, potential glyphosate ban and reduced crop yield. Based on a preliminary experiment, we shed light on the short-term effect of different types of tillage on weed communities, weed:crop interference and crop performance in fields conducted under CA principles for years. Tillage treatments significantly affected weed communities before weeding, increasing weed density and richness in comparison to no-till (including glyphosate application). These differences in species richness and abundance transcribed into a significant tillage effect on weed community composition before weeding, highlighting the importance of tillage in shaping weed communities, even after 17 years of similar farming practices. However, these significant effects observed before weeding were not visible after weeding, highlighting the tremendous potential of herbicides to homogenize initially contrasted weed flora and the difficulty to link agronomic practices and weed observations, when the latter are carried out after weeding. The highest crop yields were observed under $\mathrm{CT}$, probably due to increased mineralisation of soil organic matter or enhanced soil structure, rather than lower weed:crop competition, as reflected by an overall low weed biomass after weeding. Finally, insights for future research were proposed to avoid the implementation of phenomenological experiments (i.e., we did this, we saw that) and better investigate the processes underlying the effects of tillage on fields managed under CA principles. We argue that potential benefits of occasional ploughing will depend on the density and composition of the newly upwelled weed seedbank, which will need to be assessed before implementing tillage. From a multicriteria perspective, the long-term benefits associated with CA could largely exceed short-term yield increases associated with occasional tillage. Future studies will need to characterize the impact of occasional tillage operations on the long-term multiperformance of CA systems. 
Table 2. Guide for a better understanding of the processes underlying tillage effects on weed communities and crop performance in fields previously conducted under conservation agriculture principles.

\begin{tabular}{|c|c|c|c|}
\hline Objective & Hypothesis & Methods & Key References \\
\hline \multirow{3}{*}{$\begin{array}{l}\text { Environmental } \\
\text { conditions }\end{array}$} & $\begin{array}{l}\text { Soil tillage reduces soil moisture in the superficial horizon but increases } \\
\text { soil temperature, changes which may affect weed and crop growth during } \\
\text { the early stages. }\end{array}$ & $\begin{array}{l}\text { Sensors for assessing soil temperature and moisture before and } \\
\text { after tillage operations. }\end{array}$ & [54-56] \\
\hline & $\begin{array}{l}\text { Tillage promotes nitrogen mineralisation and hence, increases soil } \\
\text { inorganic nitrogen content since organic matter is concentrated in the top } \\
\text { soil horizon after a long sequence of no-till. }\end{array}$ & $\begin{array}{l}\text { Soil sampling before and after tillage to assess soil nitrogen content } \\
\text { and mineralisation. }\end{array}$ & [57-59] \\
\hline & Reduced crop growth may result from soil compaction. & $\begin{array}{l}\text { Soil sampling for assessing bulk density or assessment of soil } \\
\text { compaction with a penetrometer. }\end{array}$ & [60-62] \\
\hline \multirow[t]{2}{*}{ Plant growth } & $\begin{array}{l}\text { If water is not the main limiting factor, crop growth is expected to be faster } \\
\text { in tillage-based treatments because of greater absorption of soil inorganic } \\
\text { nitrogen. }\end{array}$ & $\begin{array}{l}\text { Assessment of crop nitrogen content. } \\
\text { Assessment of soil coverage dynamics, visually or with adapted } \\
\text { sensors of green cover or NDVI index. }\end{array}$ & {$[63,64]$} \\
\hline & $\begin{array}{l}\text { Changes in environmental condition are expected to modify crop and } \\
\text { weed phenology, thereby affecting crop:weed interference. }\end{array}$ & $\begin{array}{l}\text { Assessment of weed phenology (e.g., date of emergence, number of } \\
\text { seedlings per species) through repeated field scoutings }\end{array}$ & {$[65,66]$} \\
\hline $\begin{array}{l}\text { Seedbank prior to } \\
\text { the experiment }\end{array}$ & $\begin{array}{l}\text { Ploughing is expected to upwell persistent seeds of the deep seedbank } \\
\text { while superficial tillage is expected to stimulate transient weeds of the } \\
\text { superficial seedbank. }\end{array}$ & $\begin{array}{l}\text { Assessment of weed seed distribution in the soil profile before } \\
\text { tillage operations by soil samplings splitted into subsamplings } \\
\text { according to the depth of tillage treatments (i.e., } 0-10 \mathrm{~cm} \text { and } 10-30 \\
\mathrm{~cm} \text { ). Identification of weed species to forecast emerged weed } \\
\text { communities. }\end{array}$ & {$[33,37]$} \\
\hline Seed movements & $\begin{array}{l}\text { High emergence in the ploughed treatment may be due to incomplete } \\
\text { burial of weed seeds initially present in the top horizon. }\end{array}$ & $\begin{array}{l}\text { Coloured plastic beads of different sizes, weights, and densities } \\
\text { could be placed on the soil surface prior to ploughing (so as to } \\
\text { mimic weed seeds) and sampling of soil cores to assess their } \\
\text { vertical distribution after tillage. }\end{array}$ & [31] \\
\hline Long-term effects & $\begin{array}{l}\text { Despite short-term benefits, occasional tillage may negatively affect } \\
\text { long-term cropping system performance. }\end{array}$ & $\begin{array}{l}\text { Continue to assess indicators in the subsequent years on the same } \\
\text { quadrats or zones. }\end{array}$ & [67] \\
\hline \multirow{4}{*}{$\begin{array}{l}\text { Experimental } \\
\text { design }\end{array}$} & $\begin{array}{l}\text { Results may be affected by a lack of temporal and spatial replicates (i.e., } \\
\text { lack of statistical power). }\end{array}$ & $\begin{array}{l}\text { Replicate the tillage treatments within the same fields and perform } \\
\text { meta-analysis of experiments (i.e., fields). }\end{array}$ & [68] \\
\hline & The results may depend on local condition and may lack genericity. & $\begin{array}{l}\text { Implement on-farm trials with a farmers' network and precisely } \\
\text { assess environmental conditions. }\end{array}$ & [69-71] \\
\hline & $\begin{array}{l}\text { The effect of tillage on weed communities is overridden by weeding } \\
\text { operations, thereby leading to non-significant differences in yield loss due } \\
\text { to weeds across tillage systems. }\end{array}$ & $\begin{array}{l}\text { Add additional weeding treatment (i.e., paired weeded vs. } \\
\text { unweeded zones) so as assess potential yield loss between tillage } \\
\text { treatments. }\end{array}$ & [72] \\
\hline & $\begin{array}{l}\text { Superficial tillage close to sowing is expected to stimulate the weed } \\
\text { seedbank and thus, may not represent an interesting weed management } \\
\text { tactic }\end{array}$ & $\begin{array}{l}\text { Adoption of a systemic approach which allows to compare } \\
\text { different coherent types of fallow management (type and timing of } \\
\text { tillage, number of tillage operation, etc.) }\end{array}$ & {$[46,73]$} \\
\hline
\end{tabular}


Author Contributions: S.C. designed the study and funded the research. S.C., A.B. and G.A. collected the data. A.B. and G.A. analysed the data. All authors were involved in the interpretation of the results and contributed to writing the original version of the manuscript and improving the subsequent ones. All authors have read and agreed to the published version of the manuscript.

Funding: Auxence Baudron was funded by the Casdar VANCOUVER, which was financed by the French Ministry in charge of Agriculture and Food (Ministère de l'Agriculture et de l'Alimentation, with financial contribution from the special purpose account "Développement agricole et rural"). Authors also wish to acknowledge financial support from the French project CoSAC (ANR-15-CE18-0007), the French program "Investissements d'Avenir" and the project ISITE-BFC (contract ANR-15-IDEX-03).

Acknowledgments: Authors would like to thank all members of the INRAE research station "Domaine d'Epoisses" who helped to design the experiment and who carried it out with dedication (Pascal Farcy, Brice Mosa, Philippe Chamoy, Benjamin Pouilly, Alain Berthier). This experiment would never have been possible if Nicolas Munier-Jolain (INRA UMR Agroécologie) had not started a long-term Integrated Weed Management cropping system experiment in 2000 and if Pascal Farcy (INRAE UE Domaine d'Epoisses), head crop manager at the experimental farm, had not helped to introduce CA principles in one of the cropping systems.

Conflicts of Interest: The authors declare no competing interest.

\section{References}

1. Hobbs, P.R.; Sayre, K.; Gupta, R. The role of conservation agriculture in sustainable agriculture. Philos. Trans. R. Soc. B 2008, 363, 543-555. [CrossRef]

2. Reicosky, D.C. Conservation tillage is not conservation agriculture. J. Soil Water Conserv. 2015, 70, 103A-108A. [CrossRef]

3. Blanco-Canqui, H.; Wortmann, C.S. Does occasional tillage undo the ecosystem services gained with no-till? A review. Soil Tillage Res. 2020, 198, 104534. [CrossRef]

4. Antier, C.; Andersson, R.; Auskalnienè, O.; Barić, K.; Baret, P.; Besenhofer, G.; Calha, L.; Dos Santos, S.C.; De Cauwer, B.; Chachalis, D.; et al. A Survey on the Uses of Glyphosate in European Countries; INRAE: Paris, France, 2020. [CrossRef]

5. Hill, S.B.; MacRae, R.J. Conceptual framework for the transition from conventional to sustainable agriculture. J. Sustain. Agric. 1995, 7, 81-87. [CrossRef]

6. Crawford, M.H.; Rincon-Florez, V.; Balzer, A.; Dang, Y.P.; Carvalhais, L.C.; Liu, H.; Schenk, P.M. Changes in the soil quality attributes of continuous no-till farming systems following a strategic tillage. Soil Res. 2015, 53, 263-273. [CrossRef]

7. Liu, H.; Crawford, M.; Carvalhais, L.C.; Dang, Y.P.; Dennis, P.G.; Schenk, P.M. Strategic tillage on a Grey Vertosol after fifteen years of no-till management had no short-term impact on soil properties and agronomic productivity. Geoderma 2016, 267, 146-155. [CrossRef]

8. Derpsch, R.; Friedrich, T.; Kassam, A.; Li, H. Current status of adoption of no-till farming in the world and some of its main benefits. Int. J. Agric. Biol. Eng. 2010, 3, 1-25.

9. Cordeau, S.; Guillemin, J.P.; Reibel, C.; Chauvel, B. Weed species differ in their ability to emerge in no-till systems that include cover crops. Ann. Appl. Biol. 2015, 166, 444-455. [CrossRef]

10. Chauhan, B.S.; Gill, G.; Preston, C. Influence of tillage systems on vertical distribution, seedling recruitment and persistence of rigid ryegrass (Lolium rigidum) seed bank. Weed Sci. 2006, 54, 669-676. [CrossRef]

11. Nichols, V.; Verhulst, N.; Cox, R.; Govaerts, B. Weed dynamics and conservation agriculture principles: A review. Field Crop. Res. 2015, 183, 56-68. [CrossRef]

12. Lemessa, F.; Wakjira, M. Mechanisms of ecological weed management by cover cropping: A review. J. Biol. Sci. 2014, 14, 452-459. [CrossRef]

13. Teasdale, J.R. Contribution of cover crops to weed management in sustainable agricultural systems. J. Prod. Agric. 1996, 9, 475-479. [CrossRef]

14. Adeux, G.; Munier-Jolain, N.; Meunier, D.; Farcy, P.; Carlesi, S.; Barberi, P.; Cordeau, S. Diversified grain-based cropping systems provide long-term weed control while limiting herbicide use and yield losses. Agron. Sustain. Dev. 2019, 39, 42. [CrossRef]

15. Cardina, J.; Herms, C.P.; Doohan, D.J. Crop rotation and tillage system effects on weed seedbanks. Weed Sci. 2002, 50, 448-460. [CrossRef] 
16. Armengot, L.; Blanco-Moreno, J.M.; Bàrberi, P.; Bocci, G.; Carlesi, S.; Aendekerk, R.; Berner, A.; Celette, F.; Grosse, M.; Huiting, H.; et al. Tillage as a driver of change in weed communities: A functional perspective. Agric. Ecosyst. Environ. 2016, 222, 276-285. [CrossRef]

17. Thomas, A.G.; Derksen, D.A.; Blackshaw, R.E.; Van Acker, R.C.; Légère, A.; Watson, P.R.; Turnbull, G.C. A multistudy approach to understanding weed population shifts in medium- to long-term tillage systems. Weed Sci. 2004, 52, 874-880. [CrossRef]

18. Trichard, A.; Alignier, A.; Chauvel, B.; Petit, S. Identification of weed community traits response to conservation agriculture. Agric. Ecosyst. Environ. 2013, 179, 179-186. [CrossRef]

19. Dang, Y.P.; Seymour, N.P.; Walker, S.R.; Bell, M.J.; Freebairn, D.M. Strategic tillage in no-till farming systems in Australia's northern grains-growing regions: I. Drivers and implementation. Soil Tillage Res. 2015, 152, 104-114. [CrossRef]

20. Douglas, M.R.; Tooker, J.F. Slug (Mollusca: Agriolimacidae, Arionidae) Ecology and Management in No-Till Field Crops, With an Emphasis on the mid-Atlantic Region. J. Integr. Pest. Manag. 2012, 3, C1-C9. [CrossRef]

21. Peixoto, D.S.; Silva, B.M.; Oliveira, G.C.d.; Moreira, S.G.; da Silva, F.; Curi, N. A soil compaction diagnosis method for occasional tillage recommendation under continuous no tillage system in Brazil. Soil Tillage Res. 2019, 194, 104307. [CrossRef]

22. Çelik, İ.; Günal, H.; Acar, M.; Acir, N.; Bereket Barut, Z.; Budak, M. Strategic tillage may sustain the benefits of long-term no-till in a Vertisol under Mediterranean climate. Soil Tillage Res. 2019, 185, 17-28. [CrossRef]

23. Díaz-Zorita, M.; Grove, J.H.; Murdock, L.; Herbeck, J.; Perfect, E. Soil structural disturbance effects on crop yields and soil properties in a no-till production system. Agron. J. 2004, 96, 1651-1659. [CrossRef]

24. Van den Putte, A.; Govers, G.; Diels, J.; Gillijns, K.; Demuzere, M. Assessing the effect of soil tillage on crop growth: A meta-regression analysis on European crop yields under conservation agriculture. Eur. J. Agron. 2010, 33, 231-241. [CrossRef]

25. Holland, J.M. The environmental consequences of adopting conservation tillage in Europe: Reviewing the evidence. Agric. Ecosyst. Environ. 2004, 103, 1-25. [CrossRef]

26. Mirsky, S.B.; Ryan, M.R.; Curran, W.S.; Teasdale, J.R.; Maul, J.; Spargo, J.T.; Moyer, J.; Grantham, A.M.; Weber, D.; Way, T.R.; et al. Conservation tillage issues: Cover crop-based organic rotational no-till grain production in the mid-Atlantic region, USA. Renew. Agric. Food Syst. 2012, 27, 31-40. [CrossRef]

27. Dyer, W.E. Exploiting Weed Seed Dormancy and Germination Requirements through Agronomic Practices. Weed Sci. 1995, 43, 498-503. [CrossRef]

28. Cordeau, S.; Smith, R.G.; Gallandt, E.R.; Brown, B.; Salon, P.; DiTommaso, A.; Ryan, M.R. Disentangling the effects of tillage timing and weather on weed community assembly. Agriculture 2017, 7, 66. [CrossRef]

29. Cordeau, S.; Smith, R.G.; Gallandt, E.R.; Brown, B.; Salon, P.; DiTommaso, A.; Ryan, M.R. Timing of tillage as a driver of weed communities. Weed Sci. 2017, 65, 504-514. [CrossRef]

30. Burnside, O.C.; Wilson, R.G.; Weisberg, S.; Kenneth, G.H. Seed Longevity of 41 Weed Species Buried 17 Years in Eastern and Western Nebraska. Weed Sci. 1996, 44, 74-86. [CrossRef]

31. Roger-Estrade, J.; Colbach, N.; Leterme, P.; Richard, G.; Caneill, J. Modelling vertical and lateral weed seed movements during mouldboard ploughing with a skim-coulter. Soil Tillage Res. 2001, 63, 35-49. [CrossRef]

32. Mohler, C.L. A model of the effects of tillage on emergence of weed seedlings. Ecol. Appl. 1993, 3, 53-73. [CrossRef] [PubMed]

33. Mahe, I.; Cordeau, S.; Bohan, D.A.; Derrouch, D.; Dessaint, F.; Millot, D.; Chauvel, B. Soil seedbank: Old methods for new challenges in agroecology? Ann. Appl. Biol. 2020. [CrossRef]

34. Yvoz, S.; Petit, S.; Biju-Duval, L.; Cordeau, S. A framework to type crop management strategies within a production situation to improve the comprehension of weed communities. Eur. J. Agron. 2020, 115, 126009. [CrossRef]

35. Lechenet, M.; Dessaint, F.; Py, G.; Makowski, D.; Munier-Jolain, N. Reducing pesticide use while preserving crop productivity and profitability on arable farms. Nat. Plants 2017, 3, 17008. [CrossRef]

36. Lechenet, M.; Bretagnolle, V.; Bockstaller, C.; Boissinot, F.; Petit, M.-S.; Petit, S.; Munier-Jolain, N. Reconciling pesticide reduction with economic and environmental sustainability in arable farming. PLoS ONE 2014, 9, e97922. [CrossRef]

37. Vasileiadis, V.; Froud-Williams, R.; Eleftherohorinos, I. Vertical distribution, size and composition of the weed seedbank under various tillage and herbicide treatments in a sequence of industrial crops. Weed Res. 2007, 47, 222-230. [CrossRef] 
38. Chancellor, R.J. Decline of arable weed seeds during 20 years in soil under grass and the periodicity of seedling emergence after cultivation. J. Appl. Ecol. 1986, 23, 631-637. [CrossRef]

39. Mulugeta, D.; Stoltenberg, D.E. Increased weed emergence and seed bank depletion by soil disturbance in a no-tillage system. Weed Sci. 1997, 45, 234-241. [CrossRef]

40. Soltani, E.; Baskin, C.C.; Baskin, J.M.; Soltani, A.; Galeshi, S.; Ghaderi-far, F.; Zeinali, E. A quantitative analysis of seed dormancy and germination in the winter annual weed Sinapis arvensis (Brassicaceae). Botany 2016, 94, 289-300. [CrossRef]

41. Thompson, K.; Band, S.R.; Hodgson, J.G. Seed size and shape predict persistence in soil. Funct. Ecol. 1993, 7, 236-241. [CrossRef]

42. Alvarez, R.; Alvarez, C.R.; Daniel, P.E.; Richter, V.; Blotta, L. Nitrogen distribution in soil density fractions and its relation to nitrogen mineralisation under different tillage systems. Soil Res. 1998, 36, 247-256. [CrossRef]

43. Mohler, C.L.; Caldwell, B.A.; Marschner, C.A.; Cordeau, S.; Mahoud, Q.; Ryan, M.R.; DiTommaso, A. Weed seed bank and weed biomass dynamics in a long-term organic vegetable cropping systems experiment. Weed Sci. 2018, 66, 611-626. [CrossRef]

44. Grubb, P.J. The maintenance of species-richness in plant communities: The importance of the regeneration niche. Biol. Rev. 1977, 52, 107-145. [CrossRef]

45. Botto, J.F.; Scopel, A.L.; Sánchez, R.A. Water constraints on the photoinduction of weed seed germination during tillage. Funct. Plant Biol. 2000, 27, 463-471. [CrossRef]

46. Pekrun, C.; Claupein, W. The implication of stubble tillage for weed population dynamics in organic farming. Weed Res. 2006, 46, 414-423. [CrossRef]

47. Blanco-Canqui, H.; Shaver, T.M.; Lindquist, J.L.; Shapiro, C.A.; Elmore, R.W.; Francis, C.A.; Hergert, G.W. Cover crops and ecosystem services: Insights from studies in temperate soils. Agron. J. 2015, 107, 2449-2474. [CrossRef]

48. Grandy, A.; Robertson, G.; Thelen, K. Do productivity and environmental trade-offs justify periodically cultivating no-till cropping systems? Agron. J. 2006, 98, 1377-1383. [CrossRef]

49. Newman, M.M.; Hoilett, N.; Lorenz, N.; Dick, R.P.; Liles, M.R.; Ramsier, C.; Kloepper, J.W. Glyphosate effects on soil rhizosphere-associated bacterial communities. Sci. Total Environ. 2016, 543, 155-160. [CrossRef]

50. Sullivan, T.P.; Sullivan, D.S. Vegetation management and ecosystem disturbance: Impact of glyphosate herbicide on plant and animal diversity in terrestrial systems. Environ. Rev. 2003, 11, 37-59. [CrossRef]

51. Nguyen, D.B.; Rose, M.T.; Rose, T.J.; Morris, S.G.; Van Zwieten, L. Impact of glyphosate on soil microbial biomass and respiration: A meta-analysis. Soil Biol. Biochem. 2016, 92, 50-57. [CrossRef]

52. Romdhane, S.; Spor, A.; Busset, H.; Falchetto, L.; Martin, J.; Bizouard, F.; Bru, D.; Breuil, M.-C.; Philippot, L.; Cordeau, S. Cover crop management practices rather than the composition of cover crop mixtures affect microbial communities in no-till agroecosystems. Front. Microbiol. 2019, 10. [CrossRef]

53. Pelosi, C.; Pey, B.; Hedde, M.; Caro, G.; Capowiez, Y.; Guernion, M.; Peigné, J.; Piron, D.; Bertrand, M.; Cluzeau, D. Reducing tillage in cultivated fields increases earthworm functional diversity. Appl. Soil Ecol. 2014, 83, 79-87. [CrossRef]

54. Nyborg, M.; Malhi, S. Effect of zero and conventional tillage on barley yield and nitrate nitrogen content, moisture and temperature of soil in north-central Alberta. Soil Tillage Res. 1989, 15, 1-9. [CrossRef]

55. Stafford, J. Remote, non-contact and in-situ measurement of soil moisture content: A review. J. Agric. Eng. Res. 1988, 41, 151-172. [CrossRef]

56. SU, S.L.; Singh, D.; Baghini, M.S. A critical review of soil moisture measurement. Measurement 2014, 54, 92-105. [CrossRef]

57. Keeney, D.; Bremner, J. Comparison and evaluation of laboratory methods of obtaining an index of soil nitrogen availability. Agron. J. 1966, 58, 498-503. [CrossRef]

58. Silgram, M.; Shepherd, M.A. The effects of cultivation on soil nitrogen mineralization. In Advances in Agronomy; Elsevier: Amsterdam, the Netherlands, 1999; Volume 65, pp. 267-311.

59. Alvarez, R.; Steinbach, H. A review of the effects of tillage systems on some soil physical properties, water content, nitrate availability and crops yield in the Argentine Pampas. Soil Tillage Res. 2009, 104, 1-15. [CrossRef]

60. Hemmat, A.; Adamchuk, V. Sensor systems for measuring soil compaction: Review and analysis. Comput. Electron. Agric. 2008, 63, 89-103. [CrossRef] 
61. Lipiec, J.; Hatano, R. Quantification of compaction effects on soil physical properties and crop growth. Geoderma 2003, 116, 107-136. [CrossRef]

62. Herrick, J.E.; Jones, T.L. A dynamic cone penetrometer for measuring soil penetration resistance. Soil Sci. Soc. Am. J. 2002, 66, 1320-1324. [CrossRef]

63. Sinclair, T.; Horie, T. Leaf nitrogen, photosynthesis, and crop radiation use efficiency: A review. Crop. Sci. 1989, 29, 90-98. [CrossRef]

64. Tremblay, N.; Wang, Z.; Cerovic, Z.G. Sensing crop nitrogen status with fluorescence indicators. A review. Agron. Sustain. Dev. 2012, 32, 451-464. [CrossRef]

65. Ghersa, C.; Holt, J. Using phenology prediction in weed management: A review. Weed Res. 1995, 35, 461-470. [CrossRef]

66. Yvoz, S.; Cordeau, S.; Zuccolo, C.; Petit, S. Crop type and within-field location as sources of intraspecific variations inthe phenology and the production of floral and fruit resources by weeds. Agric. Ecosyst. Environ. 2020, 302, 107082. [CrossRef]

67. Kandeler, E.; Tscherko, D.; Spiegel, H. Long-term monitoring of microbial biomass, N mineralisation and enzyme activities of a Chernozem under different tillage management. Biol. Fertil. Soils 1999, 28, 343-351. [CrossRef]

68. Hughes, G. The problem of weed patchiness. Weed Res. 1990, 30, 223-224. [CrossRef]

69. Jackson, L.; Ramirez, I.; Yokota, R.; Fennimore, S.; Koike, S.; Henderson, D.; Chaney, W.; Calderón, F.; Klonsky, K. On-farm assessment of organic matter and tillage management on vegetable yield, soil, weeds, pests, and economics in California. Agric. Ecosyst. Environ. 2004, 103, 443-463. [CrossRef]

70. Ingram, J. Technical and social dimensions of farmer learning: An analysis of the emergence of reduced tillage systems in England. J. Sustain. Agric. 2010, 34, 183-201. [CrossRef]

71. Hagmann, J. Farmer participatory research in conservation tillage; approach, methods and experiences from an adaptive on-farm trial programme in Zimbabwe. In Proceedings of the 4th Annual Scientific Conference of the Southern Africa Development Community (SADC) Land and Water Management Research, Southern Africa Center for Coordination of Agricultural Research (SACCAR), Gaborone, Botswana, 11-14 October 1993; pp. 217-236.

72. Adeux, G.; Vieren, E.; Carlesi, S.; Bàrberi, P.; Munier-Jolain, N.; Cordeau, S. Mitigating crop yield losses through weed diversity. Nat. Sustain. 2019, 2, 1018-1026. [CrossRef]

73. Akobundu, I.; Ekeleme, F.; Chikoye, D. Influence of fallow management systems and frequency of cropping on weed growth and crop yield. Weed Res. 1999, 39, 241-256. [CrossRef]

Publisher's Note: MDPI stays neutral with regard to jurisdictional claims in published maps and institutional affiliations.

(C) 2020 by the authors. Licensee MDPI, Basel, Switzerland. This article is an open access article distributed under the terms and conditions of the Creative Commons Attribution (CC BY) license (http://creativecommons.org/licenses/by/4.0/). 